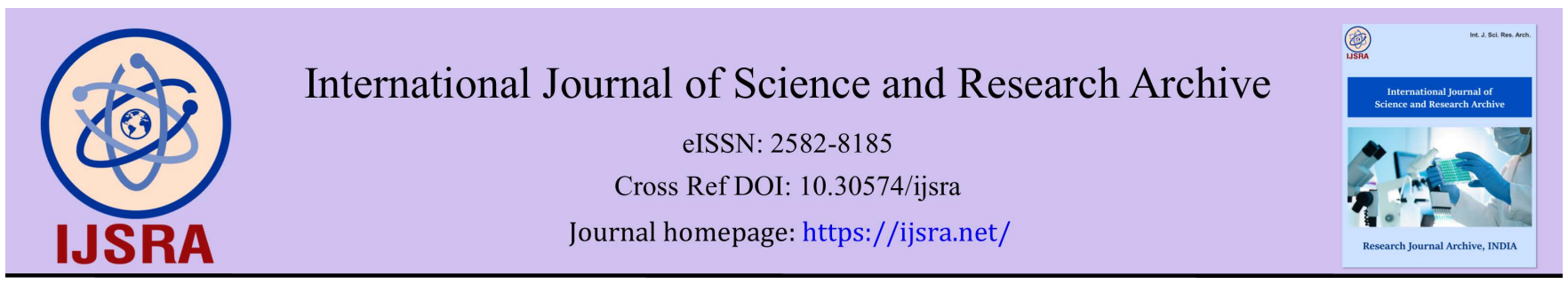

(RESEARCH ARTICLE)

\title{
Mesh size and gear type in riparian communities of Amassoma and Ogoubiri at Igbedi Creek, Bayelsa State
}

\author{
Edubamo Davidson Binaebi * and Cyrian Ogheneakpobo Orovwigho \\ Department of Fisheries, Niger Delta University, Wilberforce Island, PMB 071 Bayelsa State NG, 560103, Amassoma, \\ Nigeria.
}

International Journal of Science and Research Archive, 2022, 05(01), 123-132

Publication history: Received on 12 January 2022; revised on 18 February 2022; accepted on 20 February 2022

Article DOI: https://doi.org/10.30574/ijsra.2022.5.1.0048

\begin{abstract}
Fisheries resources exploitation is an open access business in Nigeria and the instrument or gear utilized come in various forms, sizes and shapes. The mesh sizes and gear types were investigated in riparian communities of Amassoma and Ogoubiri at Igbedi creek, Bayelsa State with the objectives to note the mesh sizes and gear types utilized in these communities. A total of 100 structured questionnaires was administered and retrieved from active fishers in the landing sites. Descriptive statistics such as simple percentage method, tables and charts were used to examine the mesh size and gear types utilized in the study area. The results obtained from the study revealed that the mesh sizes used ranges

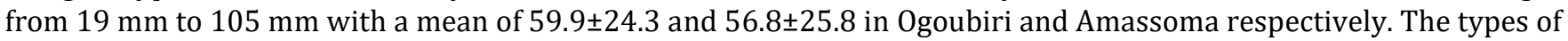
gear recorded were gillnet (45.6\%), cast net (7.7\%), purse seine net (5.3\%), beach seine net (14.7\%), drift net (1.5\%), hook and line $(10.4 \%)$ and traps (14.8\%). The length of nets utilized ranged from $68 \mathrm{~m}$ to $200 \mathrm{~m}$ at the study area. The study established that mesh sizes and gear types in use at the study area may lead to overexploitation of fish species in the study area. The survey of the mesh sizes and gear types used for fishing in riparian communities of Amassoma and Ogoubiri landing sites in Igbedi creek call for urgent need for intervention on the part of Government for policy review and implementation, so as to ensure sustainable use of the aquatic resources.
\end{abstract}

Keywords: Mesh size; Gear; Length; Landing site; Igbedi Creek

\section{Introduction}

A riparian community is an area of land along or adjacent a water course. It may be an area covered by vegetation, wildlife or a human settlement. A riparian community is characterized by three major attributes: land with a population or community of biota surrounded by a water system. The water system may be a river, pond, lake, stream and the ocean. The interaction between the community in biota and the aquatic environment will determine a healthy ecosystem. A human riparian community is characterized by utilization of the water resources, for drinking, washing clothes, transportation, sand mining, oil exploitation, fishing etc.

Fishing is one of the salient occupations of human settlements along the coast around the world [1]. These activities result in the exploitation of different size of fish for subsistence or trade purpose. Nigeria is a nation endowed with water resources with numerous riparian communities that explores the water for fish. The water resources of Nigeria include the freshwater, brackish and marine resources with artisanal fishery from the adjacent communities utilizing various fishing facilities such as gear and crafts. Fishing gears are designed to catch specific species and size of economic value [1]. This includes gears with mesh and those without mesh.

\footnotetext{
${ }^{*}$ Corresponding author: Edubamo Davidson Binaebi

Department of Fisheries, Niger Delta University, Wilberforce Island, PMB 071 Bayelsa State NG, 560103, Amassoma, Nigeria. 
Fisheries resources exploitation utilizes instrument or gears of various forms, sizes and shapes in Nigeria. The human settlements around aquatic system and increasing demand for water resources had led to high levels of habitat and biota loss [2]. Human activities had resulted in environmental degradation, introduction of foreign species and over exploitation etc. [3]. The scaling of mesh size utilized at Kianji Lake [4] revealed that only 7 out of 30 species were captured with $5 \mathrm{~cm}$ mesh size after maturity indicating vulnerability of all commercially important immature species to overfishing. Increase in mesh size from 5 to $7 \mathrm{~cm}$ revealed that about 14 out of 30 commercial important species would be allowed to reproduce at least once before they were captured [5]. Gear size regulation is an important tool in fisheries resource exploitation and management. Fish catch is a common activity of man in the environment where they are found [6]. Fishing is carried out in all riparian communities globally including Nigeria. Fish exploitation in Nigeria lacks the needed care to ensure sustainability as various traditional and modern fishing gears are utilized [7]. Knowledge of the mesh size and gear types utilized for harvesting fish is an important information for policy making as was the example of the inland Fisheries Decree 108 of 1992, which was enacted largely from the research work of National Institute for Freshwater Fisheries Research (NIFFR) on the fish and fisheries of Kainji Lake, the first and largest manmade lake in Nigeria [5,8]. Amassoma and Ogoubiri are riparian communities involved in fishing utilizing various tool. There is no relevant documentation on mesh size and gear type been utilize in the riparian communities of Amassoma and Ogoubiri axis at Igbedi creek, hence the justification of this study. This study is aimed at investigating the gears and mesh sizes used in riparian communities of Amassoma and Ogoubiri at Igbedi Creek in Bayelsa State.

\section{Material and methods}

The study was carried out at Amassoma and Ogoubiri Axis of Igbedi Creek, a large drainage system in the Niger Delta

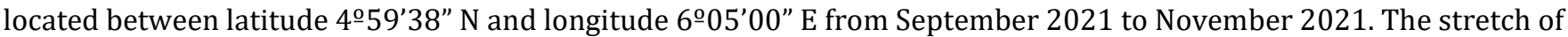
the river is a long and wide meander whose outer concave bank is relatively shallow with sandy points bars [9]. The depth and width of the river vary slightly at different points [7]. The minimum and maximum widths are 200 and 250 meters respectively. The river is subjected to tidal influence in the dry season. Water flows rapidly in one direction during the flood (May-October). At the peak of the dry season, the direction flow is slightly reversed by the rising tide.

\subsection{Research Design}

This study adopted a survey research design. A structured questionnaire was prepared along with personal interview of individual fishers in the communities in the study area.

\subsection{Data Collection}

Data for this study were collected from primary source consisting of interview schedule and structured questionnaire.

\subsection{Sampling Methods}

A total number of 100 structured questionnaires were given to the fishers in the study area. The total number of 100 structured questionnaires were retrieved and the information obtained from the questionnaires includes:

- Personal data of the fishers which include; gender, age, marital status, household size, fishing purpose and fishing experience.

- The mesh size in use in these riparian communities.

- The gear types in use in these communities.

\subsection{Data Analysis}

In analysing the data, descriptive statistics such as simple percentage method was used to analyse the data collected [10]. Also, tables and chart were used to examine the mesh size and gear types utilized in riparian communities in Amassoma and Ogoubiri axis at Igbedi Creek in Bayelsa State.

\section{Results and discussion}

\subsection{Social Characteristics of Fishers}

The social characteristics of the fishers on the landing sites were analysed. These characteristics include; gender, age, marital status, household size, fishing purpose and fishing experience. The percentage distribution of the social characteristics of fishers at the landing sites is provided in table 1 below. 
Table 1 Percentage distribution of the social characteristics of fishers

\begin{tabular}{|c|c|c|c|c|c|}
\hline \multirow[t]{2}{*}{$\mathbf{S} / \mathbf{n}$} & \multirow[t]{2}{*}{ Parameter } & \multicolumn{2}{|c|}{ Frequency } & \multicolumn{2}{|c|}{ Percentage of respondents } \\
\hline & & Ama. & Ogb. & Ama. & Ogb. \\
\hline \multicolumn{6}{|c|}{ Gender } \\
\hline a. & Male & 48 & 42 & 96 & 84 \\
\hline b. & Female & 2 & 8 & 4 & 16 \\
\hline \multicolumn{6}{|c|}{ Age } \\
\hline a. & $10-15$ yrs. & - & - & & \\
\hline b. & $16-20$ yrs. & - & - & & \\
\hline c. & $21-25$ yrs. & 3 & 4 & 6 & 8 \\
\hline d. & $26-30$ yrs. & 4 & 3 & 8 & 6 \\
\hline e. & $31-36$ yrs. & 13 & 16 & 26 & 32 \\
\hline f. & 36 and above & 30 & 27 & 60 & 54 \\
\hline \multicolumn{6}{|c|}{ Marital Status } \\
\hline a. & Married & 32 & 33 & 64 & 66 \\
\hline b. & Single & 12 & 12 & 24 & 24 \\
\hline c. & Widow & 1 & 1 & 2 & 2 \\
\hline $\mathrm{d}$. & Widower & 5 & 4 & 10 & 8 \\
\hline \multicolumn{6}{|c|}{ Household Size } \\
\hline a. & $1-5$ & 25 & 28 & 50 & 56 \\
\hline b. & $6-10$ & 23 & 22 & 46 & 44 \\
\hline c. & 10 and above & 2 & & 4 & \\
\hline \multicolumn{6}{|c|}{ Fishing Purpose } \\
\hline a. & Commercial & 6 & 5 & 12 & 10 \\
\hline $\mathrm{b}$. & Subsistence & 1 & 4 & 2 & 8 \\
\hline c. & Both & 43 & 41 & 86 & 82 \\
\hline \multicolumn{6}{|c|}{ Fishing Experience } \\
\hline a. & $1-5 \mathrm{yrs}$. & 20 & 23 & 40 & 46 \\
\hline b. & 6-10 yrs. & 17 & 17 & 34 & 34 \\
\hline c. & $11-15$ yrs. & 9 & 8 & 18 & 16 \\
\hline d. & $16-20$ yrs. & 2 & - & 4 & 0 \\
\hline e. & $21-25$ yrs. & 2 & 2 & 4 & 4 \\
\hline $\mathrm{d}$. & $26-30$ yrs. & - & - & 0 & 0 \\
\hline f. & 30 yrs. and above & - & - & 0 & 0 \\
\hline
\end{tabular}




\subsection{Gender}

The research revealed that all 100 fishers sampled were of both sexes. A total number of 48 males and 2 females were recorded in Amassoma representing 96\% and 4\% respectively of fishers sampled. Ogoubiri had 42 males and 8 females representing $84 \%$ and $16 \%$ respectively of fishers sampled at the landing site.

\subsection{Age}

The age of fishers as investigated ranged from 21 years and above indicating an adult population. In Amassoma, the age group of 21-25 years were 3 representing 6\%, 26-30 years were 4 representing 8\%, and 31-35 years were 13 representing $26 \%$ and 36 years and above were 30 representing $60 \%$ of fishers sampled at the landing site. Meanwhile, Ogoubiri recorded the age group of 21-25 years as 4 representing 8\%, 26-30 years as 3 representing 6\%, 31-35 years as 16 representing $32 \%$ and 36 and above as 27 representing $54 \%$ of fishers sampled at the landing site.

\subsection{Marital Status}

The marital status of the fishers sampled at Amassoma was recorded and the total number of married fishers (32), single (12), widow (1) and widower (5) representing 64\%, 24\%, 2\% and 10\% respectively of the fishers sampled at the landing site. Also, Ogoubiri had a record of married fishers (33), single (12), widow (1) and widower (4) representing 66\%, $24 \%, 2 \%$ and $8 \%$ respectively of total fishers sampled at the landing site.

\subsection{Household Size}

From Table 4.1 above, the household size of fishers was recorded and the group of 1-5 occupants was 25 representing 50\%, 6-10 was 23 representing 46\%, 10 and above was 2 representing 4\% in Amassoma axis. Ogoubiri landing site in the other hand, recorded 1-5 occupants as 28 representing $56 \%$ and 6-10 as 22 representing $44 \%$.

\subsection{Fishing Purpose}

The purpose of fishing was investigated and it was recorded that at Amassoma landing sites, commercial purposes was 6 representing 12\%, subsistence was 1 representing $2 \%$ and for both purposes was 43 representing $86 \%$. Meanwhile, Ogoubiri landing site recorded commercial as 5 representing $10 \%$, subsistence as 4 representing $8 \%$ and both as 41 representing $82 \%$ of fishers sampled at the landing site.

\subsection{Fishing Experience}

From Table 1 above, Amassoma with experience ranging from 1-5 years were 20 representing 40\%, 6-10 years were 17 representing 34\%, 11-15 years were 9 representing 18\%, 16-20 years were 2 representing $4 \%$ and $21-25$ years were 2 representing $4 \%$ of fishers sampled at the landing site. Also, Ogoubiri recorded 1-5 years of 20 representing 40\%, 610 years of 17 representing 34\%, and 11-15 years of 8 representing $16 \%$ and $21-25$ years of 2 representing $4 \%$.

The fishers sampled at the landing sites in this study indicated that men were more active in fishing than women. Though, the participation of women in fishing showed that there is no gender bias at the study area. This is in agreement with the findings of $[1,11$, and 12] which reported that women actively participate in fishing activities in most parts of Nigeria.

The most active age group involved in fishing activities in this study fell within the age group of 21 and above which means that they were more of youths. The findings of this study correspond with the reports of $[11,13]$ stating that fishing activities are mostly done by people within the age range of 30 and above.

The observed large numbers of married fishers sampled at the landing sites in this study is similar to that of ${ }^{15}$ which reported that the artisanal sector is constituted majorly by married fishers.

The household size of the sampled fishers at the landing sites is relatively high, which is in agreement with the reports of which reported that the large household size is due to extended family members.

The relative high numbers of fishers sampled at the landing sites fishing for both subsistence and commercial purposes in this study is in agreement with the findings of [11] which reported that fishers in Igbedi creek generates estimated high income from fishing. According to [16] income of fishers to a great extent determines their ability to purchase improved fishing gears. 
Majority of fishers sampled in this study had 1 to 15 years fishing experience indicating that most of the fishers are experienced. It is in accordance with the findings of [11].

\subsection{Mesh sizes}

The mesh sizes at Amassoma and Ogoubiri are shown on table 2.

Table 2 Frequency and Percentage distribution of mesh sizes in use by fishers

\begin{tabular}{|l|l|c|c|c|c|}
\hline S/n & Mesh sizes & \multicolumn{2}{|c|}{ Frequency } & \multicolumn{2}{l|}{ Percentage (\%) } \\
\hline & & Ama. & Ogb. & Ama. & Ogb. \\
\hline 1. & $19 \mathrm{~mm}$ & 1 & 1 & 2 & 2.1 \\
\hline 2. & $24 \mathrm{~mm}$ & 1 & 1 & 2 & 2.1 \\
\hline 3. & $25 \mathrm{~mm}$ & 9 & 6 & 18 & 12.5 \\
\hline 4. & $32 \mathrm{~mm}$ & 5 & 6 & 10 & 12.5 \\
\hline 5. & $36 \mathrm{~mm}$ & 1 & 2 & 2 & 4.2 \\
\hline 6. & $38 \mathrm{~mm}$ & 3 & 3 & 6 & 6.2 \\
\hline 7. & $40 \mathrm{~mm}$ & 2 & 1 & 4 & 2.1 \\
\hline 8. & $46 \mathrm{~mm}$ & 2 & 2 & 4 & 4.2 \\
\hline 9. & $50 \mathrm{~mm}$ & 3 & 1 & 6 & 2.1 \\
\hline 10. & $54 \mathrm{~mm}$ & 2 & 4 & 4 & 8.2 \\
\hline 11. & $56 \mathrm{~mm}$ & 5 & 3 & 10 & 6.2 \\
\hline 12. & $58 \mathrm{~mm}$ & - & 4 & - & 8.2 \\
\hline 13. & $60 \mathrm{~mm}$ & - & 2 & - & 4.2 \\
\hline 14. & $64 \mathrm{~mm}$ & 5 & - & 10 & - \\
\hline 15. & $70 \mathrm{~mm}$ & 1 & 1 & 2 & 2.1 \\
\hline 16. & $74 \mathrm{~mm}$ & - & 1 & - & 2.1 \\
\hline 17. & $76 \mathrm{~mm}$ & 1 & 2 & 2 & 4.2 \\
\hline 18. & $78 \mathrm{~mm}$ & 1 & 1 & 2 & 2.1 \\
\hline 19. & $80 \mathrm{~mm}$ & 1 & 1 & 2 & 2.1 \\
\hline 20. & $86 \mathrm{~mm}$ & 5 & 2 & 10 & 4.2 \\
\hline 21. & $90 \mathrm{~mm}$ & - & 1 & - & 2.1 \\
\hline 22. & $100 \mathrm{~mm}$ & 1 & 2 & 2 & 4.2 \\
\hline 23. & $105 \mathrm{~mm}$ & 1 & 1 & 2 & 2.1 \\
\hline Total & & 50 & 48 & 100 & 100 \\
\hline Source; Field survey from questionnaire. Ama= Amassoma, 0gb= 0goubiri \\
\hline
\end{tabular}

Table 2 above shows the frequency of mesh sizes in use at the study area. The number of mesh size in use at Amassoma are 19 different mesh sizes ranging from $19 \mathrm{~mm}-105 \mathrm{~mm}$ and at Ogoubiri 20 different mesh sizes were recorded which ranged from $24 \mathrm{~mm}-105 \mathrm{~mm}$.

There were 23 different mesh sizes; $19 \mathrm{~mm}, 24 \mathrm{~mm}, 25 \mathrm{~mm}, 32 \mathrm{~mm}, 36 \mathrm{~mm}, 40 \mathrm{~mm}, 46 \mathrm{~mm}, 50 \mathrm{~mm}, 54 \mathrm{~mm}, 56 \mathrm{~mm}, 58$ $\mathrm{mm}, 60 \mathrm{~mm}, 64 \mathrm{~mm}, 70 \mathrm{~mm}, 76 \mathrm{~mm}, 78 \mathrm{~mm}, 80 \mathrm{~mm}, 86 \mathrm{~mm}, 90 \mathrm{~mm}, 100 \mathrm{~mm}$ and $105 \mathrm{~mm}$ recorded at the landing sites. In this study, the data obtained from the landing sites of Amassoma and Ogoubiri in Igbedi creek revealed that $51 \%$ of 
the fishers utilizes mesh size below $50 \mathrm{~mm}$ which catches immature fish species as reported by $[1,5,17,18,19,20]$. This can lead to overfishing if proper regulations are not enforced.

\subsection{Gear Type}

The gear types in use as investigated at the landing sites are gillnet, cast net, purse seine net, beach seine net, hook and line, drift net and traps. The frequency and percentage of various fishing gear in use at the study area is shown in Table 3.

Table 3 Frequency and Percentage distribution of the type of gear in use by fishers

\begin{tabular}{|c|c|c|c|c|c|}
\hline \multirow[t]{2}{*}{$\mathbf{S} / \mathbf{n}$} & \multirow[t]{2}{*}{ Type of gear } & \multicolumn{2}{|c|}{ Frequency } & \multicolumn{2}{|c|}{ Percentage $(\%)$} \\
\hline & & Ama. & Ogb. & Ama. & Ogb. \\
\hline 1. & Gillnet & 31 & 28 & 55.4 & 35.9 \\
\hline 2. & Cast net & 5 & 5 & 8.9 & 6.4 \\
\hline 3. & Purse seine net & 3 & 4 & 5.4 & 5.1 \\
\hline 4. & Beach seine net & 10 & 9 & 17.9 & 11.5 \\
\hline 5. & Drift net & 1 & 1 & 1.8 & 1.3 \\
\hline 6. & Hook and Line & 3 & 12 & 5.4 & 15.4 \\
\hline \multirow[t]{2}{*}{7.} & Traps & 3 & 19 & 5.4 & 24.4 \\
\hline & TOTAL & 56 & 78 & 100.0 & 100.0 \\
\hline
\end{tabular}

The observed fishing gears in the study were gillnets, cast nets, purse seine net, beach seine nets, Drift nets, hook and line, and Traps which is similar to the findings of $[1,21,22]$ which reported the use of these gears in several parts of Nigeria

\subsection{Length of Nets}

The various net length used in Ogoubiri and Amassoma axis at Igbedi creek was investigated and the results indicated that the lengths of nets utilized in Ogoubiri ranged from $90-200 \mathrm{~m}$. Meanwhile, at Amassoma axis of Igbedi Creek the length of nets ranged from $68 \mathrm{~m}-200 \mathrm{~m}$ as shown in figure 1 below.

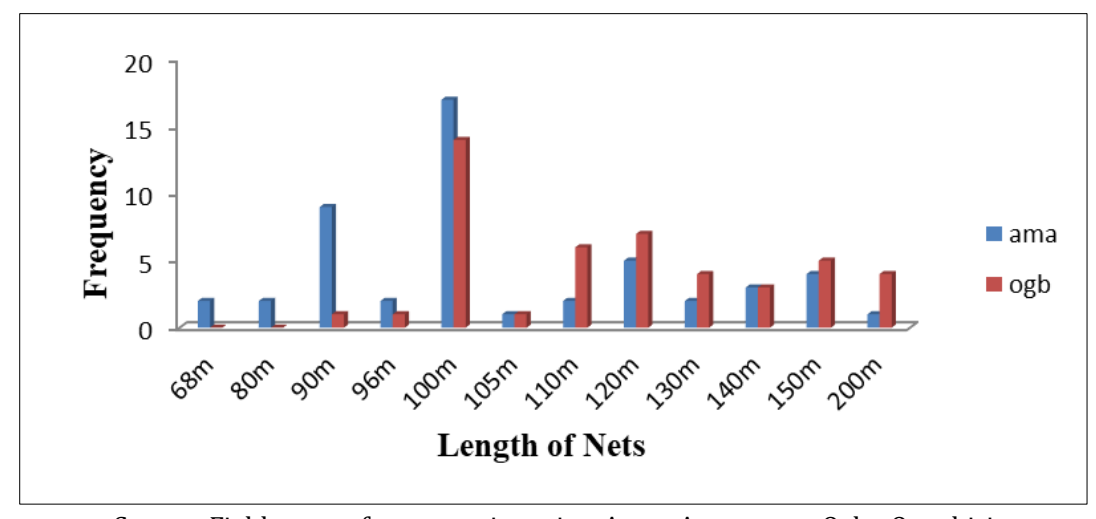

Source: Field survey from questionnaire; Ama= Amassoma; Ogb= Ogoubiri

Figure 1 Frequency of Net length at Amassoma and Ogoubiri axis in Igbedi creek

The length of nets utilized at the landing sites in this study area recording were $68 \mathrm{~m}, 80 \mathrm{~m}, 90 \mathrm{~m}, 96 \mathrm{~m}, 100 \mathrm{~m}, 105 \mathrm{~m}$, $110 \mathrm{~m}, 120 \mathrm{~m}, 130 \mathrm{~m}, 140 \mathrm{~m}, 150 \mathrm{~m}$ and $200 \mathrm{~m}$ as the length of nets in use. The result of this study is similar to that of [1] which recorded $73.15 \mathrm{~m}, 77.72 \mathrm{~m}, 91.44 \mathrm{~m}$ and $121.92 \mathrm{~m}$ as length of nets used in riparian communities in NewCalabar River and the Bonny estuary, Port Harcourt, Rivers State, Nigeria. 


\subsection{Other Gear Types}

From the investigation, it was evident that other types of gear used in the study area were hook and line, agura trap and shrimp trap. In Amassoma, the total number of hook and line used were 6 and the hooks per line ranges from 12 to 32 with an average of $26.3 \pm 7.6$ and 1 as the average number of lines per fisher as shown in table 4. Agura trap recorded a total of 3 from sampled fishers with length ranging from 47 to $52 \mathrm{~cm}$, width from 37 to $62 \mathrm{~cm}$ and diameter of 18 to 24 $\mathrm{cm}$ with a mean length of $49 \pm 2.6$, mean width of $46.3 \pm 13.7$ and mean diameter of $20.7 \pm 3.1$ respectively. A total number of 1 was recorded as shrimp trap with a length of $44 \mathrm{~cm}$, width of $67 \mathrm{~cm}$ and diameter of $18 \mathrm{~cm}$. At Ogoubiri 16 hook and line were recorded and the hooks per line ranging from 18 to 60 with an average of $34.6 \pm 13.4$ and $1.3 \pm 0.4$ as the average number of lines per fisher. Table 4.5 below, agura trap had a total number of 10 from sampled fishers at the landing site with length ranging from 42 to $80 \mathrm{~cm}$, width from 34 to $96 \mathrm{~cm}$ and diameter 18 to $26 \mathrm{~cm}$ having a mean length of $55.4 \pm 12.2$, mean width of $63.6 \pm 18.9$ and mean diameter of $21.4 \pm 2.7$ respectively. Shrimp trap was recorded as 5 with length ranging from 50 to $76 \mathrm{~cm}$, width from 34 to $44 \mathrm{~cm}$ and diameter from 28 to $44 \mathrm{~cm}$ with a mean \pm SD value of $65.4 \pm 11.1,39.2 \pm 4.5$ and $36.4 \pm 7.1$ respectively.

Table 4 Frequency, total and mean \pm SD of Other Gear Types at Amassoma Landing Site in Igbedi Creek

\begin{tabular}{|c|c|c|c|c|}
\hline $\mathbf{S} / \mathbf{n}$ & \multicolumn{4}{|c|}{ Gear type } \\
\hline 1. & Hook and line & \multicolumn{2}{|c|}{ Hooks per line } & Number of lines per fisher \\
\hline i. & & \multicolumn{2}{|c|}{12} & 1 \\
\hline ii. & & \multicolumn{2}{|c|}{24} & 1 \\
\hline iii. & & \multicolumn{2}{|c|}{28} & 1 \\
\hline iv. & & \multicolumn{2}{|c|}{30} & 1 \\
\hline v. & & \multicolumn{2}{|c|}{32} & 1 \\
\hline vi. & & \multicolumn{2}{|c|}{32} & 1 \\
\hline \multicolumn{2}{|c|}{ Total } & \multicolumn{2}{|c|}{158} & 6 \\
\hline \multicolumn{2}{|c|}{ Average } & \multicolumn{2}{|c|}{$26.3 \pm 7.6$} & 1 \\
\hline 2. & Agura trap & Length(cm) & Width(cm) & Diameter (cm) \\
\hline i. & & 47 & 62 & 24 \\
\hline ii. & & 48 & 37 & 18 \\
\hline iii. & & 52 & 40 & 20 \\
\hline \multicolumn{2}{|c|}{ Total } & 147 & 139 & 62 \\
\hline \multicolumn{2}{|c|}{ Mean \pm SD } & $49 \pm 2.6$ & $46.3 \pm 13.7$ & $20.7 \pm 3.1$ \\
\hline 3. & Shrimp trap & Length $(\mathrm{cm})$ & Width (cm) & Diameter(cm) \\
\hline i. & & 44 & 67 & 18 \\
\hline
\end{tabular}

The observed fishing gears were traditional fishing tools as reported by $[11,23,24]$. Gura trap, shrimp trap and also hook and line were recorded by all parties as other gears utilized at the study areas. 
Table 5 Frequency, Total and Mean \pm SD of Other Gear Types at Ogoubiri Landing Site in Igbedi Creek

\begin{tabular}{|c|c|c|c|c|}
\hline \multirow{2}{*}{$\frac{S / n}{1 .}$} & \multicolumn{4}{|l|}{ Gear type } \\
\hline & Hook and line & \multicolumn{2}{|c|}{ Hooks per line } & Number of line per fisher \\
\hline i. & & \multicolumn{2}{|c|}{44} & 2 \\
\hline ii. & & \multicolumn{2}{|c|}{36} & 2 \\
\hline iii. & & \multicolumn{2}{|c|}{33} & 1 \\
\hline iv. & & \multicolumn{2}{|c|}{32} & 1 \\
\hline $\mathrm{V}$. & & \multicolumn{2}{|c|}{36} & 1 \\
\hline vi. & & \multicolumn{2}{|c|}{24} & 1 \\
\hline vii. & & \multicolumn{2}{|c|}{18} & 2 \\
\hline viii. & & \multicolumn{2}{|c|}{60} & 1 \\
\hline ix. & & \multicolumn{2}{|c|}{38} & 2 \\
\hline $\mathrm{x}$. & & \multicolumn{2}{|c|}{16} & 1 \\
\hline xi. & & \multicolumn{2}{|c|}{60} & 1 \\
\hline xii. & & \multicolumn{2}{|c|}{48} & 1 \\
\hline xiii. & & \multicolumn{2}{|c|}{26} & 1 \\
\hline xiv. & & \multicolumn{2}{|c|}{36} & 1 \\
\hline $\mathrm{XV}$. & & \multicolumn{2}{|c|}{20} & 1 \\
\hline xvi. & & \multicolumn{2}{|c|}{26} & 1 \\
\hline \multicolumn{2}{|c|}{ Total } & \multicolumn{2}{|c|}{553} & 20 \\
\hline \multicolumn{2}{|c|}{ Average } & \multicolumn{2}{|c|}{$34.7 \pm 13.4$} & $1.3 \pm 0.4$ \\
\hline 2. & Agura trap & Length(cm) & Width(cm) & Diameter (cm) \\
\hline i. & & 80 & 96 & 26 \\
\hline ii. & & 46 & 56 & 20 \\
\hline iii. & & 42 & 76 & 26 \\
\hline iv. & & 54 & 68 & 20 \\
\hline $\mathrm{V}$. & & 44 & 34 & 20 \\
\hline vi. & & 66 & 76 & 20 \\
\hline vii. & & 47 & 40 & 18 \\
\hline viii. & & 50 & 78 & 22 \\
\hline ix. & & 65 & 58 & 20 \\
\hline $\mathrm{x}$. & & 60 & 54 & 22 \\
\hline \multicolumn{2}{|c|}{ Total } & 554 & 636 & 214 \\
\hline \multicolumn{2}{|c|}{ Mean \pm SD } & $55.4 \pm 12.2$ & $63.6 \pm 18.9$ & $21.4 \pm 2.7$ \\
\hline 3. & Shrimp trap & Length(cm) & Width(cm) & Diameter(cm) \\
\hline i. & & 60 & 35 & 44 \\
\hline ii. & & 50 & 43 & 38 \\
\hline iii. & & 76 & 44 & 28 \\
\hline iv. & & 65 & 40 & 30 \\
\hline $\mathrm{v}$. & & 76 & 34 & 42 \\
\hline \multicolumn{2}{|c|}{ Total } & 327 & 196 & 182 \\
\hline Aver & & $65.4 \pm 11.1$ & $39.2 \pm 4.5$ & $36.4 \pm 7.1$ \\
\hline
\end{tabular}




\section{Conclusion}

The study establishes that mesh sizes in use at Amassoma and Ogoubiri landing sites in Igbedi creek if not regulated can lead to over exploitation of fish species in the creek which will in turn lead to depletion of fish species. The survey of the mesh sizes and gear types used for fishing in riparian communities of Amassoma and Ogoubiri landing sites in Igbedi creek call for urgent need for intervention on the part of Government for policy implementation, so as to ensure sustainable use of the aquatic resources.

\section{Compliance with ethical standards}

\section{Acknowledgments}

We appreciate Miss Cyrian Ogheneakpobo Orovwigho for her commitment in this study.

Special thanks to Mrs Rose Orovwigho, Rev. Fr Paul Orovwigho and Hon. Moses Anaughe for their financial support during this study. Great appreciation to our supervisor for his assistance, encouragement and fatherly supervision.

\section{Disclosure of conflict of interest}

There was no conflict of interest.

\section{Statement of informed consent}

Informed consent was obtained from all individual participants included in the study.

\section{References}

[1] Binaebi DE, Jamabo NA. Mesh and Gear types in riparian communities in New-Calabar River and Bonny Estuaries, Port-Harcourt, Rivers State, Nigeria. Department of Fisheries and Aquatic Environment, Rivers State University. International Journal of Agriculture and Earth Science. 2018; 4(6): 20 - 33.

[2] Arthington HA, William G, Nicholas KD and Ian JW. Aquatic conservation in freshwater and marine ecosystems Wiley online library; 2016.

[3] Dudgeon D, Artington AH, Gessner MO, Kawabata ZI, knowler DJ, Leveque C, Naiman RJ, Richard AH, Soto D, Stiassny MLJ, Sullivian CA. Freshwater biodiversity: importance, threats, status and conservation challenges. Biological reviews. 2006; 81: 163-182.

[4] Ita EO. Contributions to the dynamics of mean size statistics in a changing fishery. 1 Family Githarinidae in Kianji Lake, Hydro bio-logic. 1980; 68(3): 269-277.

[5] Ita EO. Inland Fisheries Resources of Nigeria. CIFA Occasional Paper No 20. FAO Rome; 1993.

[6] Craig JF, Halls AS, Barr JJF, Bean CW. The Bangladesh floodplain fisheries research, 2004; 66: 271-286.

[7] Sikoki FD, Hart AI, Abowei JFN Gill net selectivity and fish substance in the lower Nun River, Nigeria journal of applied science and environment management. 1998; I: 13-19.

[8] Ovie SI, Raji A. Food security and poverty alleviation through improved valuation and governance of river fisheries in Africa Fisheries co-management in Nigeria: an Analysis of the underlying policy process. National Institute for Freshwater Fisheries Research. PMB. 6006. New Bussa, Niger State, Nigeria; 2006.

[9] Abowei JFN. Aspects of fisheries of lower Nun River Nigeria [Ph.D. Thesis] University of Port Harcourt; 2000.

[10] Cooper DR. Schindler PS, Business Research Methods (9th edition). USA Mc Graw-Hill; 2006.

[11] Kwen KI, Davies OA, Binyotubo TE. Survey of fishing gear and status of Fishers in Igbedi Creek, Nigeria Delta, Nigeria. International Journal of Scientific Research in Knowledge (IJSRK). 2013; 11: 493-501.

[12] Adeyemo A0. Challenges faced by fishers at Igbedi Creek, Wilberforce Island, Bayelsa State, Nigeria.Nigerian Journal of Fisheries. 2011; 8(2): 346-351.

[13] Sanni AO, Ayanda JO, Alhassan DA, Adabayo CO, Bako WS. Assessment of the adoption of aquaculture technologies in Niger Delta, North Central Nigeria, In: R.J. Koko and A.M. Orire (Eds.), Proceedings of the 26th 
Annual Conference of the Fisheries Society of Nigeria (FISON). 28th Nov. to 2nd Dec., Minna, Niger State, Nigeria. 2011; 59-65.

[14] Tagago TA, Ahmed YB. Fishing gear survey of Tatabu floodplain, In: R.J. Koko and A.M. Orire (Eds.), Proceedings of the 26th Annual Conference of the Fisheries Society of Nigeria (FISON). 28th Nov. to 2nd Dec., Minna, Niger State, Nigeria. 2011; 109-116.

[15] Oloaya OJ, Odebiye OC, Omoyinmi GAK, Akintayo IO, Udolisa REK, Ezeri GNO, Hundeyin-Agoro OC. The socioeconomic analysis of small scale fish farmers in Lagos State fishfarm estate, Ikorodu, Nigeria, In: R.M. Koko and A.M. Orire (Eds.), Proceedings of the 26th Annual Conference of the Fisheries Society of Nigeria (FISON). 28th Nov. to 2nd Dec., Minna, Niger State, Nigeria. 2011; 214-222.

[16] Agbontale 0. Motivational factors responsible for women involvement in fish processing and marketing around Lake Kainji, In: O.A. Fagbenro, O.A. Dada and M.O. Olufayo (Eds.), Proceedings of the 24th Annual Conference of the Fisheries Society of Nigeria (FISON), Oct. 26th to 28th, Akure, Ondo State. 2009; 57-60.

[17] Enyenihi UK. Biological conservation for environmental stability and food production. Trans. Nig. Soc. Boil. Conserve 1990; 4(1): 10.

[18] Eyo AA. Provost alerts federal. Government over foreign fishermen In Lake Kainji. In The Guardian Newspaper Thursday. 2004; 21(9,451): 50.

[19] Seisay MDB, Du Feu TA. The Effect of Long Term Exploitation by Gill Net Fishery on the Multi-Species Fish Stocks In Kainji Lake. Nigerian Germany Kainji Lake Fisheries Promotion Project Technical Report Series. $1997 ; 11: 58$.

[20] Jamabo NA, Ibim AT. Utilization and protection of the brackish water ecosystem of the Niger Delta for sustainable fisheries development. World Journal of Fisheries Development. 2010; 2: 138-141.

[21] Bankole NO, Raji A, Adikwu IA, Okwundu EC. Fishing Gear Survey of Lake Alau. In: A.A. Eyo and E.A. Ajao (Eds.), Proceedings of the 16th Annual Conference of the Fisheries Society of Nigeria (FISON). 2003; 99-103.

[22] Kingdom T, Kwen K. Survey of Fishing Gear and Methods in the Lower Taylor Creek Area, Bayelsa State, Nigeria. World Journal of Fish and Marine Sciences. 2009; 1(4): 313-319.

[23] Davies OA, Kwen K, Status and constraints of artisanal fishers in the Lower Taylor Creek Area, Niger Delta, Nigeria. Journal of Aquatic Sciences. 2013; 28(1): 1-8.

[24] Moses BS. Introduction to tropical fisheries (2nd Edition), Ibadan University Press; 1992. 